\title{
MEMADUKAN KEMBALI EKSOTERISME DAN ESOTERISME DALAM ISLAM
}

\author{
Syamsuri \\ Fakultas Ushuluddin dan Filsafat UIN Syarif Hidayatullah \\ Jl. Ir. H. Juanda No. 95 Ciputat, Jakarta, 15419 \\ e-mail: syams_fuf@yahoo.com
}

\begin{abstract}
Abstrak: Di kalangan sebagian Muslim terjadi kesenjangan pemahaman terhadap dimensi eksoterisme (dimensi lahir, syariat) dan esoterisme (dimensi batin, tasawuf) Islam. Bagi yang mengutamakan dimensi eksoterisme, dimensi esoterisme dianggap tidak penting dan bahkan kadang-kadang keluar dari ajaran Islam. Sementara yang mengutamakan dimensi esoteris memandang bahwa eksoterisme tidak diperlukan lagi, karena manusia sudah mampu menyingkap rahasia Tuhan. Sejatinya, antara dimensi eksoterisme dan esoterisme ini tidak dapat dipisah-pisahkan. Keduanya merupakan bagian ajaran Islam yang integral. Tulisan ini hendak mengungkapkan tarik-menarik pemahaman antara dimensi eksoterisme dan esoterisme Islam. Pada akhirnya, penulis menyimpulkan bahwa dimensi esoterisme (tasawuf) diperlukan manusia agar terjadi perimbangan dalam menghadapi hidup dan lebih memberi ruh dari pemahaman syariat yang dianggap kaku dan kering.
\end{abstract}

\begin{abstract}
Reintegrating Exoterisme and Esoterisme in Islam. There have been a misnderstanding amonngst some Muslims between the exoteric of rituals or syariah and the esoteric dimension of tasawuf or mystisism in Islam. Those who give more weight for exoteric dimension regarded the esoteric of no great concern and even sometimes have departed from the Islamic teachings. For those who support the esoteric dimension, however, considered the exoteric to be unusefull, since man had been able to uncover the mystery of God. Ideally, the exoteric and esoteric dimensions are separate whole, both of which are an integrated part of Islamic tenets. This essay, is going to shed some lights on esoteric and exoteric dimension of Islam. The author concludes that the esoteric dimension of tasawuf is need by human being so that equilibrium can be maintained in facing their lives and will give more spiritual impetus in understanding the deemed rigid and wither syariah.
\end{abstract}

Kata Kunci: tasawuf, fikih, esoterisme, eksoterisme, pemikiran Islam 


\section{Pendahuluan}

Seperti agama lain, Islam memiliki dua dimensi, dimensi luar (eksoterik, lahir) yang mengambil bentuk syariat, dan dimensi dalam (esoterik, batin) yang kemudian mengambil bentuk tasawuf. Tarekat (jalan spiritual) yang dikenal lebih popular dengan nama tasawuf adalah dimensi batin dan esoterik Islam. Sebagai jantung ajaran Islam, tasawuf seperti juga jantung manusia tersembunyi dari pandangan, meskipun ia menjadi sumber batin kehidupan dan menjadi pusat yang mengatur seluruh organisme keagamaan Islam. Sementara syariat adalah hukum Tuhan yang membuat seseorang menjadi Muslim dengan menerimanya. Hanya dengan hidup sesuai ajaran syariat orang dapat mencapai keseimbangan yang menjadi dasar untuk memasuki tasawuf (tarekat). Hanya orang yang dapat berjalan di tanah datar yang dapat berharap untuk dapat mendaki gunung. Tanpa menjalani syariat, kehidupan tasawuf adalah mustahil, dan sesungguhnya di dalam tasawuf terjalin hal-hal yang diterangkan dalam syariat. Baik tasawuf maupun syariat kedua-duanya bersumber dari al-Qur'an dan Sunnah Nabi. ${ }^{1}$

Seorang penganut Islam yang benar adalah seorang yang menghayati dan melaksanakan kedua dimensi tersebut secara seimbang. Akan tetapi dalam kenyataannya terdapat sekelompok masyarakat Muslim yang penghayatan keislamannya lebih mengutamakan dimensi luar atau lahirnya saja, yang kemudian terkenal dengan sebutan Ahl Zhâhir atau kaum Syariat. Kelompok ini dalam keberagamaannya lebih menitikberatkan perhatian pada segi-segi syariat atau hukum yang bersifat formal legalistik. Selain itu banyak pula di antara masyarakat Islam yang penghayatan keislamannya lebih mengutamakan dimensi dalam atau batinnya, yang kemudian dikenal kaum Batini dan kaum Tarekat (Ahlal-Bâthin).

Ibrâhîm al-Randi menjelaskan bahwa kaum Muslim dalam ibadah mereka terbagi menjadi dua. Kelompok pertama adalah mereka yang orientasi keislaman lebih menitik beratkan pada hukum-hukum luar (al-ahkâmm al-zhawâhir) yakni segi-segi lahiriah. Sedangkan kelompok kedua adalah mereka yang lebih menitikberatkan pada hukum-hukum dalam (al-ahkâm al-dhamâir), yakni segi-segi batiniah. ${ }^{2}$ Lewat tulisan ini, akan digambarkan hubungan kedua dimensi tersebut dalam pemikiran Islam dan pandangan pemikir Barat terhadap tasawuf Islam.

\section{Rekonsiliasi Tasawuf dan Syariat dalam Pemikiran Ulama}

Beberapa sufi tradisional, terutama dari golongan Syâdziliyyah, menggunakan lambang lingkaran untuk menggambarkan hubungan antara kedua dimensi dasar Islam ini. Dari setiap titik dalam ruang dapat dibuat lingkaran dan jari-jari dalam jumlah tidak terhingga

${ }^{1}$ Seyyed Hossein Nasr, Ideals and Realities of Islam (Chicago: ABC International, 1999), h. 121; Seyyed Hossein Nasr, Islamic Life and Thought (Chicago: ABC International, 2001), h. 193.

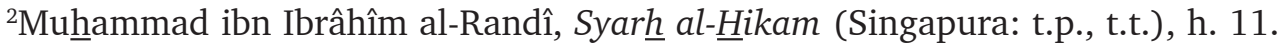


yang menghubungkan setiap titik dalam lingkaran dengan pusat lingkaran. Lingkaran ini adalah syariat yang keseluruhannya membentuk masyarakat Muslim. Setiap Muslim yang mengakui Hukum Tuhan adalah sebuah titik dalam lingkaran ini. Jari-jari melambangkan thurûq (bentuk ganda dari tharîqah). Setiap jari-jari adalah jalan yang menuju ke pusat. Para sufi mengatakan bahwa jumlah jalan yang menuju Tuhan sama banyaknya dengan jumlah keturunan Adam. Tharîqah (tarekat), yang terdiri dari berbagai bentuk, sesuai dengan kebutuhan dan temperamen spiritual manusia, adalah jari-jari yang menghubungkan setiap titik ke pusat. Hanya dengan berdiri di dalam lingkaran, yaitu menerima syariat, manusia dapat mencari jalan yang menuju ke pusat. Hanya dengan menjalani syariat kemungkinan terbukanya pintu kehidupan spiritual dapat disadari. Di pusat terletak hakikat atau kebenaran, yang menjadi sumber tarekat dan syariat. Laksana titik yang membentuk lingkaran dan jari-jari, begitu pula hakikat menciptakan tarekat dan syariat, hakikat itu "ada dan tidak ada". Syariat dan tarekat diciptakan oleh Tuhan yang menjadi Kebenaran. Keduanya mencerminkan hakikat dengan cara yang berbeda. Menjalani syariat adalah hidup dalam mencerminkan hakikat, sebab lingkaran adalah refleksi pusat. Ini adalah cara yang penting dan mencukupi untuk mencapai kehidupan yang utuh dan sejahtera. Tetapi selalu ada orang memiliki batin sedemikian rupa sehingga mereka tidak dapat hidup hanya dalam refleksi atas hakikat, melainkan harus mencapainya. Bagi mereka, Islam adalah perjalanan ke pusat. Bagi mereka, tarekat adalah cara yang diturunkan Tuhan dengan mana mereka dapat mencapai tujuan akhir, yaitu hakikat yang menjadi asal segala hal, dari mana tradisi integral dengan hukum dan cara atau lingkaran dan jari-jari berasal. ${ }^{3}$

Dalam perjalanan sejarahnya, Islam mampu mempertahankan keseimbangan antara kedua dimensi tersebut. Akan tetapi, kadang-kadang muncul orang-orang yang memberikan penekanan pada satu segi dengan mengorbankan segi yang lainnya. Pernah ada golongan yang menolak validitas tarekat demi syariat. Beberapa di antara mereka mengaku sebagai penjaga syariat yang mempertahankan syariat dan peranan yang mutlak. Sedangkan di lain pihak mereka menerima bahkan menjalani tarekat. Mereka ini disebut ulama al-Zhâhir (ahli-ahli hukum) yang kewajibannya adalah menjaga kelangsungan syariat. Yang lain telah melangkah demikian jauh, sampai mereka menolak tarekat sama sekali, dan merasa puas dengan penafsiran agama secara lahiriah semata-mata. Mereka ini disebut ulama palsu (qishri) yang akan merusak keseimbangan antara dimensi esoterik dan eksoterik, seandainya mereka berkuasa atas seluruh masyarakat Muslim. Tetapi, meskipun sebagai reaksi terhadap dunia Barat Modern, trend tertentu yang berhubungan dengan pandangan tersebut telah mendapat dukungan di beberapa tempat, pandangan ini tidak dapat diterima oleh seluruh ortodoksi Islam dan hanya berperan secara terbatas. Bagi sebagian besar Muslim, seorang sufi tetap dipandang sebagai Muslim

${ }^{3}$ Nasr, Ideals and Realities of Islam, h. 122; Haidar Bagir, Buku Saku Tasawuf (Bandung: Arasy-Mizan Utama, 2005), h. 60. 
yang saleh dan dihormati karena kehidupan agamanya sangat dalam, meskipun apa yang ia lakukan sering tidak dapat dimengerti oleh masyarakat pada umumnya. ${ }^{4}$

Di lain pihak, ada orang-orang yang mencoba untuk merusak keseimbangan dengan memberi penekanan yang berlebihan pada tarekat saja, seolah-olah tarekat dapat bertahan dalam dunia tanpa syariat, yang menjadi perlindungannya dari berbagai pengaruh duniawi yang merusak. Sebenarnya, gerakan-gerakan yang berakhir pada penciptaan sekte atau bahkan menyimpang dari ortodoksi Islam, timbul sebagai akibat dari usaha eksteriorisasi dimensi batin tanpa bantuan syariat. Pada umumnya kebanyakan agama semu dan sekte yang menyimpang timbul dari latar belakang esoterik yang setelah berpisah dari lindungan syariat menyimpang dari sifat yang asli, yang berakhir pada pembentukan sekte kecil yang tidak berbahaya atau menjadi agama semu yang betul-betul berbahaya, tergantung pada suasana di mana gerakan itu tumbuh. ${ }^{5}$

Dalam totalitasnya, Islam telah mampu menjaga keseimbangan eksoteris dan esoteris, atau tafsir dan takwil, sejauh berhubungan dengan penafsiran al-Qur'an. Sebagian besar ortodoksi dalam masyarakat Muslim telah mampu menjaga terpisahnya syariat dari tarekat dan terasingnya tarekat dari syariat, yang akan merusak keseimbangan masyarakat Islam. Vitalitas keagamaan dan spiritual Islam timbul dari kehadiran kedua dimensi ini selama berabad-abad yang secara bersama-sama telah membentuk tradisi keagamaan integral yang mampu menciptakan masyarakat religius dan norma kehidupan batin.

Banyak ulama yang berusaha agar kedua orientasi (penghayatan) keagamaan tersebut tidak menghasilkan kepincangan yang menyalahi prinsip keseimbangan, jalan tengah (tawâzun) dalam Islam. Keduanya terintegrasi dalam penghayatan dan pengalaman keagamaan seorang Muslim. Hal ini dilakukan terutama setelah pelaksanaan hukuman mati terhadap diri al-ㅍallâj pada awal abad keempat hijriyah, yang menimbulkan kesan dalam pandangan umum bahwa apa yang disebut tasawuf itu adalah suatu kesesatan. Al- Hârits ibn Asad al-Muhâsibî (w. 837) adalah salah seorang sufi yang berusaha mengintegrasikan tasawuf dan syariat tersebut. Bagian terbesar tulisan al-Muhâsibî berkenaan dengan disiplin diri. ${ }^{6}$ Ulama lain yang berusaha melakukan rekonsiliasi antara tasawuf dan syariat adalah Abû Nashr al-Sarrâj (w. 988 M) yang menulis buku al-Luma'. Untuk menolak kesan negatif terhadap tasawuf, al-Sarrâj memberikan suatu uraian panjang bahwa tasawuf yang benar itu tidak menyimpang, bahkan tasawuf itu sendiri adalah inti dan jiwa dari ajaran Islam itu sendiri. Di samping itu, ia juga menjelaskan bermacammacam kesesatan yang terdapat di kalangan orang-orang yang disebut sufi itu, sebagai akibat dari kesalahpahaman. Al-Sarrâj berusaha keras membuktikan bahwa tasawuf

${ }^{4}$ Nasr, Ideals and Realities of Islam, h. 123.

5Ibid., h. 123.

${ }^{6}$ A.J. Arberry, Sufism: An Account of the Mystic of Islam (London: George Allen and Unwin Ltd., 1979), h. 46-47. 
sepenuhnya sesuai dengan al-Qur'an, sunah dan syariat. Banyak sufi terkemuka menjadi muridnya, baik secara langsung maupun tidak langsung. ${ }^{7}$ Sufi lainnya yang berusaha mengkompromikan tasawuf dan syariat adalah Abû Thâlib al-Makkî (w. 996). Dalam bukunya, Qûth al-Qulûb, yang mengandung lebih banyak argumen yang berhati-hati dan lebih sedikit kutipan yang aneh, al-Makkî telah berhasil membangun desain menyeluruh untuk tasawuf Sunni. ${ }^{8}$ Abû Bakr Muhammad al-Kalâbâdzî juga berupaya menemukan jalan tengah dan mendamaikan ortodoksi dengan tasawuf dengan menulis buku yang berjudul al-Ta'ârrufli Madzhab Ahl al-Tashawwûf. ${ }^{9}$

Selanjutnya sufi yang berusaha mendamaikan tasawuf dan syariat adalah Abû alQâsim al-Qusyayrî (w. 1072). Sufi ini memandang tasawuf pada masanya telah menyimpang dari perkembangannya yang pertama, baik dari segi akidah maupun moral. Dalam rangka menanggapi hal itu, ia menulis buku yang berjudul al-Risâlah untuk mengembalikan tasawuf kepada jalur yang benar, seperti tasawuf para guru golongan sufi yang telah membangun kaidah-kaidah mereka di atas prinsip-prinsip tauhid yang benar. Mereka memelihara akidahakidah mereka dari bidah dan dekat dengan tauhid kaum Salaf dan Ahli Sunah. ${ }^{10}$

Abû al-Hasan ‘Âlî ibn 'Utsmân al-Hujwîrî (w. 1076), lewat karyanya yang berjudul Kasyf al-Mahjûb, berusaha mengemukakan sebuah sistem tasawuf yang komprehensif, bukan hanya menghimpun sejumlah ajaran para guru sufi juga mendiskusikan dan menjelaskan doktrin-doktrin dan praktik-praktik para sufi. Ia tetap bersikap moderat dan menghindari kecenderungan panteistik. Lewat bukunya itu, ia memperingatkan para pembacanya agar tetap menaati syariat (hukum Islam) sebagaimana yang dicontohkan oleh semua sufi yang mencapai derajat kesucian yang tinggi. ${ }^{11}$ Demikianlah, para ulama tersebut telah memainkan peranan yang sangat penting dalam upaya mendamaikan tasawuf dan syariat dan mempertahankan ortodoksi Ahli Sunah Waljamaah. Pengaruh mereka atas perkembangan tasawuf di kemudian hari, khususnya di dunia Sunni sangat besar. ${ }^{12}$

Pada masa al-Ghazâlî (w. 1111 M), nuansa ketegangan antara tasawuf dan syariat masih ada, sehingga ia juga meneruskan usaha penyesuaian itu. Tampaknya, al-Ghazâlî memiliki modal yang lebih besar daripada apa yang dimiliki oleh para penulis sufi sebelumnya, sehingga usahanya mencapai hasil yang lebih gemilang dalam melakukan rekonsiliasi antara tasawuf dan syariat. Dalam kitabnya, Ihyâ' 'Ulûm al-Dîn, ia berusaha menghidupkan

${ }^{7}$ Ibid., h. 67.

${ }^{8}$ Arberry, Sufism, h. 68.

${ }^{9}$ Abû Bakr Muhammad al-Kalâbâdzî, The Doctrine of the Sufis, trans. A.J. Arberry (Lahore: Sh. Muhammad Ashraf, 1979).

${ }^{10}$ Abû al-Qâsim al-Qusyairî al-Naisâbûrî, Risâlah al-Qusyairiyyah fị ‘Ilm al-Tashawûf (Beirut: Dâr al-Khair, t.t.), h. 41.

${ }^{11}$ Abû al-Hasan ‘Âlî ibn 'Utsmân al-Hujwîrî, Kasyf al-Mahjûb, trans. R.A. Nicholson (London, 1976), h. 12.

${ }^{12}$ Kautsar Azhari Noer, Tasawuf Perenial Kearifan Kritis Kaum Sufi (Jakarta: Serambi, 2002), h. 190-198. 
pengalaman ilmu-ilmu agama dengan pendalaman spiritualisme tasawuf. Bagi al-Ghazâlî, tasawuf tidak untuk mengabaikan syariat, tetapi justru sebaliknya untuk menghidupkan dan menggairahkan pengamalan syariat. Pandangan tersebut tercermin dari struktur kitabnya itu. Pada juz pertama dan kedua, al-Ghazâlî mengajarkan proses pematangan ilmu syariat dan akidah. Pada juz ketiga al-Ghazâlî memberi kesempatan pada umat Islam untuk menerjuni ilmu tasawuf. Sementara pada juz keempat al-Ghazâlî mengarahkan tasawuf pada akhlak terpuji (akhlâq al-karîmah). ${ }^{13}$

Ulama lain yang berusaha melakukan rekonsiliasi tasawuf dengan syariat selain mereka adalah Ahmad Sirhindî (w. 1624 M). Ia mengkritik keras terhadap tasawuf yang dipraktikkan tanpa syariat. Menurutnya, syariat bukan semata-mata sistem aturan lahiriah (eksoterik) belaka, dan para sufi yang mencari kenyatan di luar syariat sebenarnya sedang mengejar impian. Demikianlah, ia berupaya mempertemukan nilai-nilai tasawuf dengan nilai-nilai syariat. ${ }^{14}$

Dalam menjelaskan hubungan tasawuf dengan syariat, seperti sudah dijelaskan, Seyyed Hossein Nasr berpendirian bahwa ajaran Islam itu terdiri dari dua kategori. Pertama, yang berhubungan dengan dimensi lahir atau eksoterik, yang kemudian lebih terkenal dengan istilah syariat. Kedua, yang berkaitan dengan dimensi batin atau esoterik, yang selanjutnya dikenal dengan tasawuf. Tasawuf tidak bisa dipraktikkan oleh seorang Muslim tanpa terlebih dahulu mempraktikkan ajaran-ajaran syariat secara benar. Dalam hal ini, Nasr juga menganggap penting untuk melakukan rekonsiliasi antara tasawuf dan syariat. Ia menegaskan, dalam hal yang sama dimensi batin (tasawuf) sangat erat hubungannya dengan dimensi lahir (syariat), dan dimensi lahir diperlukan sebagai dasar pijakan untuk menggapai dimensi batin, sehingga pengalaman Ilahiah yang selalu bergantung pada kondisi batin seseorang selalu berada dalam ikatan transendental. ${ }^{15}$

Menurut Nasr, beberapa ucapan sufi besar yang secara harfiah terlihat sebagai penolakan terhadap syariat, harus ditinjau dalam latar belakang kondisi yang ada dan kepada siapa ucapan tersebut ditujukan. Bila seorang Hâfizh menulis, agar orang membuang tikar sembahyangnya jauh-jauh, atau seorang Ibn al-Arabî menulis bahwa hatinya adalah kuil berhala, ini tidak berarti bahwa mereka menolak syariat. Sebetulnya mereka menunjukkan ucapan tersebut kepada orang-orang yang menjalankan syariat seenaknya saja dan mereka mengajak orang-orang ini untuk mengatasi dunia bentuk dan menerobos ke dalam arti batin syariat. Banyak perbedaan yang terdapat di antara masyarakat yang

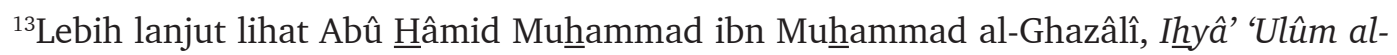
Dîn, Juz I-IV (Beirut: Dâr al-Fikr, 1980).

${ }^{14}$ Muhhammad 'Abd al- $\underline{\text { Haq }}$ al-Anshârî, Sufism and Syari'a: A Study of Syaikh Ahmad Sirhindi's Effort to Reform Sufism (Jakarta: Rajawali, 1990), h. 85-139.

${ }^{15}$ Nasr, Islamic Life and Thought, h. 193. 
setiap orang menjalankan syariat dan masyarakat yang tidak seorang pun menjalankannya. ${ }^{16}$

Dalam pengamatan Nasr, sekarang ini banyak orang yang ingin mengatasi dunia bentuk tanpa memiliki bentuk itu sendiri. Mereka ingin membakar kitab-kitab, dalam istilah Buddhis, tanpa memiliki kitab-kitab itu. Tetapi orang tidak dapat membuang apa yang tidak ia miliki. Para sufi yang mengajak manusia membuang bentuk lahiriah sebetulnya berbicara kepada mereka yang telah memiliki bentuk ini. Tidak ada bahaya bahwa orang akan jatuh di bawah bentuk, syariat selalu ada untuk mencegah bahaya serupa itu. Saat ini banyak sekali orang yang hidup tanpa bentuk religius dan tidak bisa membedakan antara mengatasi bentuk dan jatuh di bawah bentuk. Tarekat tidak dapat dicapai kecuali melalui syariat, dan penolakan terhadap tarekat bukanlah dari syariat melainkan pembatasan terhadap kebenaran sebagai bentuk lahir semata-mata. Tidak ada yang lebih mustahil dalam tujuan para sufi selain usaha untuk merusak syariat dan mengetengahkan individualisme, serta memberontak terhadap bentuk-bentuk religius seperti yang dilakukan para modernis dengan meminjam nama tasawuf. Kebebasan yang diberikan oleh tarekat melalui penerimaan dan transendensi bentuk syariat adalah antipoda kebebasan kuantitatif penolakan syariat. Yang satu menyerupai yang lain hanya dalam pengertian bahwa setan adalah kera Tuhan. Hanya orang bodoh atau orang yang tidak mau mengerti yang tidak dapat membedakan yang satu dari yang lain. Orang tidak dapat menolak eksoterisme demi esoterisme yang tidak dimilikinya. Pohon selalu dinilai dari buahnya dan tidak ada bukti yang lebih jelas tentang kesia-siaan usaha serupa itu selain buah yang getir yang tumbuh dari pohon itu. ${ }^{17}$

Kalau para pembaharu lain bersikap negatif terhadap tasawuf, bahkan menilai tasawuf sebagai salah satu penyebab kemunduran dan kejumudan umat Islam, ${ }^{18}$ Nasr malah berpendapat sebaliknya. Ia menilai sangat positif terhadap peranan tasawuf bagi perkembangan sejarah Islam. Menurut Nasr, tasawuf tidak dapat dijadikan kambing hitam atas segala problema yang dihadapi umat Islam. Kemunduran umat Islam justru disebabkan antara lain oleh penghancuran tarekat sufi oleh rasionalisme puritan seperti gerakan Wahabisme di Arab Saudi dan Ahli Hadis di India. Dengan menolak tasawuf dan mengkambinghitamkannya sebagi penyebab kemunduran umat Islam, berarti Islam telah direduksi sampai tinggal doktrin fikih yang kering kaku yang tidak akan berdaya menghadapi gempuran kebudayaan Barat. ${ }^{19}$

Padahal, tidak ada bukti yang lebih jelas tentang hubungan batin antara tarekat dan syariat selain fakta bahwa di berbagai pelosok dunia, Islam tersebar melalui tarekat.

${ }^{16}$ Nasr, Ideals and Realities of Islam, h.124.

${ }^{17}$ Ibid., h. 125.

${ }^{18}$ Muhamad ibn 'Abd al-Wahhâb (w. 1792 M), dan para pengikutnya, misalnya berpendapat bahwa kemunduran Islam disebabkan oleh berbagai macam tahayul, bidah dan khurafat, yang salah satunya berasal dari ajaran tasawuf atau tarekat yang menyimpang.

${ }^{19}$ Nasr, Islamic Life and Thought, h. 12. 
Di beberapa daerah India, Asia Tenggara dan di sebagian besar Afrika, Islam mula-mula tersebar melalui contoh pribadi para sufi dan berdirinya aliran tarekat. Kemudian sesudah itu syariat tersebar dan Islam diterima secara luas. Apabila tarekat adalah unsur yang terasing dalam Islam, seperti yang dinyatakan oleh kebanyakan orientalis, bagaimana ia dapat menjadi ujung tombak penyebaran syariat? Hubungan batin antara syariat dan tarekat telah memungkinkan penyebaran Islam di pelbagai daerah melalui para sufi dan orang suci yang telah menjadi contoh hidup spiritualitas Islam. ${ }^{20}$

Hubungan integral dan dinamis antara aspek batin (esoteris) dengan aspek lahir eksoteris), antara tasawuf dan syariat inilah yang menjadi ciri khas tasawuf Islam (mistisisme dalam Islam) yang membedakannya dari mistisisme-mistisisme di luar Islam. Karena itu, peranan tasawuf (tarekat) sebagai dimensi batin syariat telah diakui pula oleh otoritas dan pendiri mazhab Mâlikî dalam fikih, yang menekankan pentingnya peranan tasawuf dalam pemurnian etika Muslim. Imâm Mâlik pernah mengatakan, orang yang mempelajari syariat dan menolak tasawuf menjadi orang yang fasik (tafassaqa), orang yang bertasawuf dengan menolak fikih (syariat) akan menjadi zindik (tazandaqa), dan yang menerima serta mempelajari keduanya (tasawuf dan syariat) akan menjadi orang yang benar (tahaqqaqa). ${ }^{21}$ Imâm Syâfi'î, pendiri mazhab fikih terbesar di Indonesia, juga berpendirian sama yang berkata "ada tiga hal yang berarti bagiku di dunia ini yaitu kejujuran, kelakuan yang baik, dan mengikuti jejak para sufi." Bukan saja al-Ghazâlî yang menjadi ahli hukum, teolog dan sufi, yang menganggap jalan para sufi sebagai jalan yang terbaik, tetapi juga teolog Asy'âriyyah seperti Fakhr al-Dîn al-Râzî yang bukan sufi menganggap pengikut tarekat sebagai orang-orang yang melakukan pemurnian jiwa dengan melepaskannya dari ikatan kebendaan, dan menyebut mereka sebagai kelompok terbaik di antara manusia. ${ }^{22}$

Seyyed Hossein Nasr mengibaratkan, orang yang mempraktikkan tasawuf tanpa syariat, atau esoterisme tanpa eksoterisme laksana menanam pohon di awang-awang. Dalam ungkapan lain, Islam itu laksana buah kenari yang kulitnya berupa syariat, isinya adalah tasawuf (tarekat) dan minyaknya yang tidak tampak tetapi ada di mana-mana adalah hakikat. Kenari tanpa kulit tidak dapat tumbuh di dunia alamiah dan tanpa isi tidak berarti. Syariat tanpa tasawuf ibarat tubuh tanpa jiwa, dan tasawuf tanpa syariat tidak mempunyai bentuk lahiriah dan tidak akan mampu bertahan serta memanifestasikan dirinya dalam dunia ini. Bagi keutuhan dan kesempurnaan Islam tradisi keduanya mutlak diperlukan. Nasr berkesimpulan, hanya dengan menerima dan menjalankan syariat seseorang akan dapat menelusuri jalan tarekat (tasawuf) sehingga ia akan berhasil mencapai

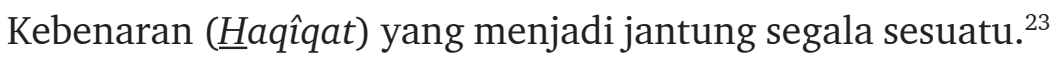

\footnotetext{
${ }^{20}$ Nasr, Ideals and Realities of Islam, h.125.

${ }^{21}$ Muhammad Zakî Ibrâhîm, Abjâdiyyat al-Tashawwuf al-Islâmî (Kairo: al-'Asyîrah alMuhammadiyyah, 1989), h. 146.

${ }^{22}$ Nasr, Ideals and Realities of Islam, h. 126.

${ }^{23}$ Ibid., h. 123.
} 
Sejalan dengan pandangan Nasr tersebut, Muhammad Zakî Ibrâhîm menjelaskan, penyatuan dari syariat dan hakikat terwujud dalam diri Nabi Muhammad SAW. Syariat adalah perkataan Nabi Muhammad SAW. tarekat adalah perbuatan Nabi Muhammad SAW., sedangkan hakikat adalah kondisi spiritual Nabi Muhammad SAW. Syariat tanpa hakikat adalah kosong, dan hakikat tanpa syariat adalah batil. Karena itu, di kalangan ulama dikenal sebuah ungkapan yang berbunyi, "barang siapa yang melaksanakan syariat tanpa memahami hakikatnya, maka ia akan menjadi fasik, dan barang siapa yang menjalani hakikat tanpa syariat, maka ia akan menjadi seorang yang zindik." ${ }^{24}$

Muhammad Zakî Ibrâhîm menjelaskan:

Jika seorang Muslim mengucapkan dua kalimat syahadat, maka tercerminlah penyatuan antara hakikat dan syariat. Syahadat tauhid (kalimat pertama) dalam dua kalimat syahadat merupakan cerminan dari hakikat, dan syahadat Nabi Muhammad SAW. merupakan cerminan dari syariat. Renungilah kalimat yang selalu kita baca setiap melaksanakan salat. Di saat kita membaca "iyyâka na'budu", maka hal tersebut merupakan perwujudan dari syariat. Ketika kita membaca "wa iyyâka nasta'în" merupakan perwujudan dari hakikat. Keduanya adalah satu. Mustahil memisahkan keduanya. Ibadah adalah lahir sebuah perintah, dan pertolongan Allah SWT. adalah bersifat batin. Setiap sesuatu pasti mempunyai sisi lahir dan sisi batin, sebagaimana jasad dan ruh manusia atau seperti air dan tempatnya." ${ }^{25}$

Bagi Muhammad Zakî Ibrâhîm, hubungan antara syariat dan hakikat itu laksana hubungan buah dengan pohonnya, laksana hubungan bunga dengan keharumannya, dan laksana bara api dengan panasnya. Semuanya adalah sesuatu yang saling bergantungan. Karena itu, satu hal yang mustahil jika dikatakan hakikat bisa tegak tanpa syariat. Syariat merupakan hakikat itu sendiri, dan hakikat tidak lain adalah syariat itu sendiri. Keduanya adalah satu, tidak akan sempurna satu sisi tanpa sisi yang lain. Allah Swt. telah menggabungkan keduanya, oleh karena itu suatu hal yang mustahil jika seseorang mau memisahkan sesuatu yang telah digabungkan oleh Allah SWT. ${ }^{26}$

Menurut Nasr bahwa tasawuf memberikan sarana yang lengkap bagi manusia untuk mencapai tujuan mulia. Tuhan sendiri memungkinkan untuk didekati dengan perjalanan dari luar (outward) menuju ke dalam (inward), sebagimana wahyu mempunyai dimensi lahir dan dimensi batin. Tasawuf juga ibarat jiwa yang menghidupkan tubuh. Tasawuf merupakan jantung (the heart) dari wahyu Islam, yang telah meniup semangatnya ke dalam seluruh struktur atau aspek ajaran Islam. Tentang pentingnya syariat dalam praktik tasawuf, Nasr menjelaskan, seluruh ibadah wajib maupun sunat akan membawa manusia menuju pantai “Keesaan”. Ibadah-ibadah pokok seperti salat, puasa, zakat, naik haji dan

\footnotetext{
${ }^{24}$ Ibrâhîm, Abjâdiyyat al-Tashawwuf al-Islâmî, h.145.

${ }^{25}$ Ibid., h.146.

${ }^{26}$ Ibid.
} 
jihad merupakan sarana untuk menyucikan kehidupan duniawi manusia, dan memungkinkan untuk hidup dan mati sebagai suatu makhluk sentral yang ditakdirkan mampu memandang kehadiran Tuhan. Ibadah-ibadah ini, bagi sufi, tidak terbatas pada bentukbentuk lahiriahnya belaka, tetapi mempunyai dimensi-dimensi batin dan tingkat-tingkat makna yang dapat dicapai manusia dengan memfungsikan keimanannya dan meningkatkan intensitas dan kualitas kebajikan (iḩsân). ${ }^{27}$

\section{Kesalahpahaman terhadap Tasawuf}

Mengomentari tentang hubungan tasawuf (tarekat) dengan syariat, Kautsar Azhari, salah seorang guru besar Fakultas Ushuluddin dan Filsafat UIN Syarif Hidayatullah, Jakarta, menjelaskan, di antara orang-orang Muslim sendiri banyak yang mengecam tasawuf. Kelompok yang mengecamnya memandang bahwa tasawuf adalah aliran dan gerakan yang ditambahkan kepada Islam (bidah) setelah periode Nabi Muhammad SAW. Menurut mereka, tasawuf bukan asli Islam, tidak pernah diajarkan dan dipraktikkan oleh Nabi Muhammad SAW. Di mata mereka, tasawuf adalah aliran sesat, atau paling tidak merugikan umat Islam. Di antara para sufi sendiri, ada sebagian yang mengecam sebagian yang lain karena yang pertama menganggap bahwa yang terakhir menganut tasawuf palsu. Tidak mengherankan jika beberapa tuduhan terhadap tasawuf sering dilontarkan oleh para pengecamnya. Tuduhan-tuduhan itu timbul karena kesalahpahaman mereka tentang tasawuf. ${ }^{28}$

Salah satu tuduhan adalah bahwa tasawuf mengabaikan atau tidak mementingkan syariat. Tuduhan ini berlaku hanya bagi kasus-kasus tertentu yang biasanya terdapat dalam tasawuf tipe "keadaan-mabuk" (sukr, intoxication), yang dapat dibedakan dengan tasawuf tipe "keadaan-tidak-mabuk" (shahw, sobriety). "Keadaan mabuk" dikuasai oleh perasaan kehadiran Tuhan: para sufi melihat Tuhan dalam segala sesuatu dan kehilangan kemampuan untuk membedakan antara makhluk-makhluk. Keadaan ini disertai oleh keintiman (uns), rasa kedekatan Tuhan yang mencintai. "Keadaan-tidak-mabuk" dipenuhi rasa takut dan hormat (haybah), rasa bahwa Tuhan betapa agung, perkasa, penuh murka, dan jauh, yang tidak peduli pada persoalan-persoalan kecil umat manusia. ${ }^{29}$

Menurut Kautsar bahwa para sufi "yang mabuk" merasakan keintiman dengan Tuhan dan sangat yakin pada kasih sayang-Nya, sedangkan para sufi "yang-tidak-mabuk" dikuasai oleh rasa takut dan hormat kepada Tuhan dan tetap khawatir terhadap kemurkaanNya. Para sufi "yang-mabuk" cenderung kurang mementingkan syariat dan menyatakan dengan terang-terangan persatuan dengan Tuhan, sedangkan para sufi "yang-tidak-mabuk" memelihara kesopanan ( $a d a b$ ) terhadap Tuhan. Para sufi yang dalam ungkapan Ibn 'Arabî,

\footnotetext{
${ }^{27}$ Nasr, Islamic Life and Thought, h. 193-196.

${ }^{28}$ Noer, Tasawuf Perenial, h. 17.

${ }^{29}$ Ibid., h. 18.
} 
"melihat dengan kedua mata" selalu memelihara akal dan kasyf (penyingkapan intuitif) dalam keseimbangan yang sempurna dengan tetap mengakui hak-hak "yang-tidak-mabuk" dan "yang-mabuk". Karena itu, tuduhan bahwa tasawuf mengabaikan syariat tidak dapat diterima apabila ditunjukkan kepada tasawuf tipe "keadaan tidak mabuk" karena tasawuf tipe ini sangat menekankan pentingnya syariat. Tasawuf tipe ini tidak dapat dipisahkan dari syariat karena bagi para penganutnya syariat adalah jalan awal yang harus ditempuh untuk menuju tasawuf. ${ }^{30}$

Dalam suatu bagian al-Futûhâat al-Makkiyyah, Ibn 'Arabî menjawab pertanyaan tentang apa yang dimaksud dengan tasawuf. “Jika anda bertanya, 'apa itu tasawuf?' kami menjawab: [tasawuf adalah] mengingat diri kepada kelakuan-kelakuan baik menurut syara' secara lahir dan batin, dan itu adalah akhlak mulia." Ungkapan "kelakuan-kelakuan baik menurut syara' (al-adab al-syar'iyyah) dalam perkataan Ibn 'Arabî ini menunjukkan bahwa tasawuf harus berpedoman kepada syara' atau syariat. Menurut sufi ini, syariat adalah timbangan dan pemimpin yang harus diikuti dan ditaati oleh siapa saja yang menginginkan keberhasilan tasawuf. ${ }^{31}$

Untuk mengetahui lebih jauh tentang siapa saja sufi-sufi yang menganut dan mengembangkan tasawuf tipe "keadaan mabuk" dan tasawuf tipe "keadaan tidak mabuk" dapat disimak dalam penjelasan al-Hujwîrî (w. 1073-1076 M) dalam kitab Kasyf al-Mahjûb. Dalam kitab tersebut, ia menyebut dua belas aliran tasawuf yang masing-masing menganut ajaran tasawuf yang dinilai berasal dari tokoh sufi abad ketiga Hijriyah. Sepuluh aliran di antaranya dinilai sebagai aliran tasawuf yang benar, sedangkan dua di antaranya dianggap sebagai aliran tasawuf yang menyimpang. Para sufi abad ketiga Hijriyah itu dibagi pula oleh al-Hujwîrî menjadi dua kelompok besar. Pertama, para sufi yang memandang keadaan mabuk (sukr) atau ekstasi lebih utama daripada keadaan sadar (sahw) dan kedua, para sufi yang berpandangan sebaliknya. Abû Yazîd al-Busthâmî, al-ㅂallâj, Ibn 'Athâ', alSyiblî, Bundar ibn ㅂusain, Abû Hamzah al-Baghdâdî, Sumnûn al-Muhibb, dan sejumlah tokoh sufi Irak, dimasukkannya ke dalam golongan pertama. Sedangkan al-Junaid alBaghdâdî, al- Muhâsibî, Sahl ibn 'Abd Allâh, Abû Ja'far al-ㅍaddâd, Hamdûn al-Qashshâr, dan Abû Muhammad ibn Khafîf dimasukkannya ke dalam kelompok kedua. Dari ucapanucapan para sufi yang termasuk kelompok pertama tadi dapat ditemukan bibit-bibit ajaran yang selanjutnya dikembangkan oleh Ibn 'Arabî dalam sistem ajaran waḩdat al-wujûd. Sedangkan dari kelompok kedua dapat ditemukan bibit-bibit ajaran tasawuf yang dikembangkan oleh al-Ghazâlî. Dua aliran besar tasawuf tersebut pada gilirannya berkembang di seluruh dunia Islam. ${ }^{32}$

\footnotetext{
${ }^{30}$ Kautsar Azhari Noer, "Memahami Tasawuf: Suatu Tanggapan terhadap Beberapa Tuduhan," dalam Ahmad Najib Burhani (ed.), Manusia Modern Mendamba Allah Renungan Tasawuf Positif (t.t.p.: t.p., t.t.) h. 81-82.

${ }^{31} \mathrm{Ibn}$ al-Arabi, al-Futûhât al-Makkiyyah, 4 Vol (Beirut: Dâr al-Fikr, t.t.), h. 128.

${ }^{32}$ Al-Hujwîrî, Kasyf al-Mahjûb, h. 176-266.
} 
Menurut Kautsar bahwa Islam adalah agama yang menekankan keseimbangan memanifestasikan dirinya dalam kesatuan syarîah (Hukum Tuhan) dan tharîqah (jalan spiritual, yang sering disebut tasawuf). Apabila syariat adalah dimensi eksoterik Islam, yang lebih banyak berurusan dengan aspek lahiriah, maka tarekat adalah dimensi esoterik Islam, yang lebih banyak berurusan dengan aspek batiniah. Pentingnya menjaga kesatuan syariat dan tharîqah dituntut oleh kenyataan bahwa segala sesuatu di alam ini, termasuk manusia, mempunyai aspek lahiriah dan aspek batiniah. Aspek lahiriah adalah manifestasi aspek batiniah. Menekankan salah satu aspek dan mengabaikan aspek lain akan menimbulkan ketidakseimbangan dan kekacauan. ${ }^{33}$

Landasan metafisis bagi pemeliharaan keseimbangan antara aspek lahiriah dan aspek batiniah dengan keharusan menyatukan syarî‘ah dan tharîqah adalah teori bahwa alam dan seluruh isinya adalah "penampakan diri" (tajallî, self-disclosure, theophany) Tuhan, yaitu penampakan nama-nama dan sifat-sifat Tuhan. Teori "penampakan diri" Tuhan adalah dasar pandangan dunia tasawuf. Tuhan mengatakan bahwa "Dia adalah Yang Awal (alAwwâl) dan Yang Akhir (al-Âkhir), Yang Lahir (al-Zhâhir) dan Yang Batin (al-Bâthin). Karena Tuhan adalah Yang Lahir dan Yang Batin, maka segala sesuatu dalam alam ini sebagai penampakan diri Tuhan mempunyai aspek lahiriah dan batiniah. Aspek lahiriah mempunyai gerak menjauh dan memisah dari Tuhan sebagai Pusat, yang tidak lain adalah Yang Batin. Aspek batiniah mempunyai kecenderungan untuk menggerak kembali kepada Tuhan sebagai Sumbernya. Mengabaikan salah satu dari kedua aspek ini adalah mengingkari kodrat manusia, yang selalu cenderung berusaha memenuhi kebutuhan lahiriah dan batiniah, atau material dan spiritual. ${ }^{34}$

Namun, tujuan akhir hidup manusia adalah kembali kepada Tuhan. Firman Tuhan yang dikutip di atas, "Dia adalah Yang Awal dan Yang Akhir," berarti bahwa Dia adalah sumber segala sesuatu dan tempat kembali segala sesuatu. Pengertian firman ini sejalan dengan firman-Nya, "Sesungguhnya kita adalah milik Allah dan kepada-Nya kita kembali" (Q.S. al-Baqarah/2: 156). Perjalanan yang harus ditempuh oleh manusia adalah perjalanan dari yang lahir kepada yang batin, dari pinggir lingkaran keberadaan kepada Pusat Yang Transenden. Perjalanan ini akan sampai kepada tujuannya bila dilakukan dengan melalui dua jalan yaitu syarî‘ah dan tharîqah akan membawa manusia kepada tujuannya, yaitu haqîqah (Realitas Terdasar, Ultimate Reality, yaitu Tuhan). Tiga dimensi agama Islam ini, syariat, tarekat dan hakikat dari suatu sudut pandangan, sejajar dengan tiga dimensi lain, Islâm, Imân dan Ih sân..${ }^{35}$ Sebutan al-Qur'an untuk fenomena yang oleh generasi-generasi Muslim belakangan disebut "tasawuf" adalah ihhsân (berbuat kebaikan), suatu kualitas ilahi dan insani yang banyak sekali diungkapkan oleh al-Qur'an, yang secara khusus

${ }^{33}$ Noer, Tasawuf Perenial, h. 20.

${ }^{34} I$ Ibid., h. 21.

${ }^{35}$ Frithjof Schuon, Understanding Islam, trans. Macleod Matheson (London: Allen and Unwin, 1963), terutama bab 4. 
menyebutkan bahwa Allah mencintai orang-orang yang mempunyai kualitas ini. Dalam hadis yang terkenal, Nabi Muhammad SAW. mendeskripsikan ihhsân sebagai dimensi terdalam dari Islam, setelah Islâm ("penyerahan diri" atau perbuatan yang benar) dan îmân

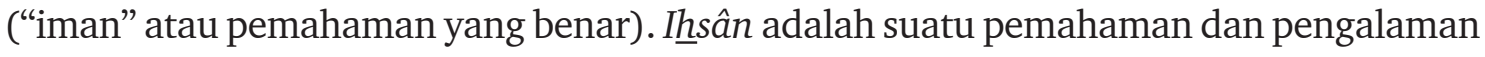
yang dalam kata-kata hadis tadi, membolehkan seseorang menyembah Allah seolah-olah anda melihat-Nya" (antabuda Allâh kaannaka tarâhu). Ini berarti bahwa para sufi selalu berusaha keras untuk menyadari kehadiran Tuhan dalam alam dan diri mereka sendiri dan untuk berbuat sebaik-baiknya. Secara historis, islâm termanisfestasi melalui syarî‘ h (syariat) dan fikih, sedangkan îmân terlembaga melalui kalâm (ilmu kalam) dan bentukbentuk ajaran doktrinal. Dengan cara yang sama, ihsân memperlihatkan kehadirannya terutama melalui ajaran-ajaran dan praktik-praktik sufi. ${ }^{36}$

Dengan mengodifikasikan syariat, fikih menetapkan cara yang tepat bagi manusia untuk menyerahkan dirinya kepada Tuhan. Ilmu Kalam mendeskripsikan kandungankandungan iman. Tasawuf memusatkan perhatian untuk memberikan hak yang penuh kepada penyerahan diri dan iman. Tasawuf dalam arti ini adalah jalan utama menuju Tuhan. Tasawuf, yang diidentifikasikan dengan ih $\underline{h a ̂ n}$, adalah jalan atau tahap tertinggi yang harus ditempuh melalui islâm dan îmân terlebih dahulu. Tasawuf, dengan demikian, adalah intisari agama Islam. ${ }^{37}$

Sejalan dengan pandangan Nasr dan Kautsar tersebut, Haidar Bagir menegaskan, di antara masalah-masalah yang kontroversial tentang tasawuf adalah anggapan bahwa kaum sufi menyepelekan keharusan menaati kewajiban-kewajiban syariat. Barangkali tidak ada anggapan tentang tasawuf yang lebih salah dari ini. Kerena sesungguhnya tidak ada satu pun tokoh tasawuf sepanjang sejarah yang pernah menyatakan atau menunjukkan sikap meremehkan syariat. Sebaliknya justru merupakan suatu ciri menonjol tasawuf adalah ketaatan pada syariat. Kaum sufi pada saat yang sama dikenal sebagai 'âbid atau 'ubbâd (para ahli ibadah). Bahkan, dalam pandangan mereka, tidak ada jalan lain untuk menempuh tasawuf (tharîqah) kecuali melalui penyelenggaraan ibadah-ibadah syariat. Semakin menjadi sufi seseorang, maka semakin intens ibadah-ibadah yang dilakukannya. Dengan kata lain, tingkatan kesufian seseorang justru ditentukan oleh intensitas ibadahnya. ${ }^{38}$

Selain itu, hampir semua kitab standar tasawuf selalu mengutip hadis tentang inhsân. Inssân adalah beribadah kepada Allah seolah-olah engkau melihat-Nya; atau, kalau engkau tidak dapat melihat-Nya, percaya bahwa Dia melihatmu. Hal ini karena umumnya kaum sufi mengidentikkan tasawuf dengan ihsân. Artinya, tasawuf pada intinya adalah beribadah kepada Allah SWT. Hanya saja, dalam tasawuf ditekankan agar ibadah hendaknya tidak semata-mata gerakan-gerakan fisik yang kosong, melainkan penuh khusyû́ dan

\footnotetext{
${ }^{36}$ Noer, Tasawuf Perenial, h. 22.

${ }^{37}$ Noer, "Memahami Tasawuf," h. 83-85.

${ }^{38}$ Bagir, Buku Saku Tasawuf, h. 139
} 
$k h u d h \hat{u}^{\prime}$ (menghadirkan hati dengan penuh kerendahan di hadapan Allah). Hadis lain yang biasa dikutip dalam buku-buku tasawuf adalah tentang hamba-hamba Allah yang mendekatkan diri secara terus-menerus dangan melakukan ibadah sunnah, sehingga Allah mencintainya, Dia menjadi matanya untuk melihat, telinganya untuk mendengar, kakinya untuk berjalan dan seterusnya. Lagi-lagi di sini ibadah dipahami oleh kaum sufi sebagai inti tasawuf. Adalah kaum sufi juga yang menekankan bahwa salat sebagai tangga (mi'râj) kaum Mukmin. Bahwa salatlah yang bisa membawa seseorang bertemu dengan Allah. Demikian juga halnya puasa, haji, zakat, bersedekah dan sebagainya. Sudah merupakan suatu kelaziman bahwa para sufi secara khusus membahas kegiatan-kegiatan ibadah mah $\underline{\text { dhah }}$ (ritual) dalam buku-buku mereka, dan itu tidak terbatas pada para sufi "ortodoks" seperti al-Ghazâlî, melainkan juga dalam karya-karya para sufi lain seperti Ibn 'Arabî dan Sayyid Haidar Amuli. Bagi kaum sufi, syariat adalah landasan tasawuf (tharîqah), sedangkan tharîqah adalah jalan menuju hakikat (haqî̀qah/ kebenaran sejati). ${ }^{39}$

Sejalan dengan itu, kaum sufi amat menekankan perlunya manusia menahan diri dari nafsu-nafsu duniawi demi mendekatkan diri kepada Allah. Al-Qusyairî, penulis kitab Risâlah al-Qusyairiyyah, ${ }^{40}$ misalnya menyatakan bahwa tanpa syariat seseorang tidak akan berhasil meraih hakikat. Bahkan, menurutnya, hakikat identik dengan syariat, dan sebaliknya. Abû Bakr Muhammad al-Kalâbâdzî, penulis buku al-Ta'arrufli Madzhab Ahl al-Tashawwuf, juga berupaya menemukan jalan tengah dan mendamaikan ortodoksi dengan tasawuf. Dalam buku tersebut dia menyatakan bahwa kewajiban menjalankan perintah-perintah syariat mengikat siapa pun, bahkan para wali yang telah mencapai tingkat tertinggi. Tidak ada satu maqâm (tataran) pun yang membuat orang yang telah meraihnya bebas dari kewajiban syariat. Justru sebaliknya, makin tinggi maqâm seseorang dalam tasawuf, seharusnya makin keraslah kesetiaannya terhadap ajaran-ajaran syariat. Al-Hujwîrî, penulis KasyfalMahjûb, menisbahkan kemunafikan kepada orang-orang yang mengaku sufi, tetapi tidak menjalankan perintah-perintah syariat. Bahkan Ibn Arabî, tokoh sufi yang pikiran-pikirannya seringkali disalahpahami orang sehingga dituduh sebagai kafir itu, mendefinisikan tasawuf sebagai "mengikatkan diri kepada perilaku-perilaku terpuji menurut syariat baik secara lahir maupun batin". ${ }^{41}$

Kesalahpahaman tersebut mungkin lahir dari adanya suatu kelompok tertentu dalam sejarah tasawuf yang disebut sebagai malâmatiyyah, yang mendedahkan diri terhadap celaan orang. Kelompok ini berpendapat bahwa untuk dapat terjauhkan dari dunia dan dekat kepada Allah mereka harus mendedahkan diri mereka kepada celaan-celaan orang lain. Semakin banyak mereka dicela dan semakin rendah kedudukan mereka di hadapan

${ }^{39}$ Ibid., h. 140-141

${ }^{40}$ Abû al-Qâsim al-Qusyairî al-Naisâbûrî, Risâlah al-Qusyairiyyah fỉ 'Tlm al-Tashawwuf (Beirut: Dâr al-Khair, t.t.)

${ }^{41}$ Ibn al-Arabî, al-Futûhât al-Makkiyyah, Vol. II (Beirut: Dâr al-Fikr, t.t.), h. 128; Bagir, Buku Saku Tasawuf, h. 141-143. 
manusia, menurut kelompok ini, maka semakin mungkin mereka untuk bersikap rendah diri di hadapan Allah. Meski pendapat seperti ini bukannya sama sekali tidak berdasar, namun hal ini terkadang disalahgunakan orang-orang yang tidak bertanggungjawab. Ada sekelompok di antara orang-orang yang mengaku sufi seperti ini (mustashwifin, kaum 'berlagak sufi') menampilkan diri sebagai orang-orang yang tidak menjalankan perintah syariat agar orang menganggap buruk dan mencela mereka. Terhadap kelompok (yang menyalahgunakan pandangan kaum malâmatiyyah) seperti ini, al-Hujwîrî bersikap amat keras dengan menyatakan bahwa mereka telah nyata-nyata melakukan kesalahan, kejahatan, dan mengumbar nafsu. Yang mereka cari sesungguhnya hanyalah popularitas di mata orang. Dengan kata lain, tindakan-tindakan mereka yang seolah-olah agar tidak populer itu justru hanyalah untuk mencari popularitas. Berbeda dengan kaum malâmatiyyah sejati, ${ }^{42}$ yang memang sudah populer (sebagai sufi), orang-orang seperti ini biasanya tidak dikenal orang. Mereka sama sekali bukan ahli atau tokoh tasawuf, alias bukan siapa-siapa. Dengan demikian, jelaslah bahwa kaum sufi tidak pernah meremehkan syariat, sebaliknya mereka menempatkan syariat pada posisi yang tidak bisa ditawar-tawar lagi. Bahkan, bagi mereka, tidak ada tasawuf, tidak ada pencapaian hakikat tanpa syariat. Tegasnya, maqâm kesufian seseorang sepenuhnya sangat tergantung pada intensitasnya dalam menjalankan perintahperintah syariat. ${ }^{43}$

Karena tasawuf merupakan "jantung" (the heart) ajaran Islam, tidak semua orang bisa mencapai tingkat tertinggi spiritualitas tasawuf. Dalam kenyataannya, umat Islam terbagi menjadi dua golongan besar, golongan khawas dan golongan awam. Pada golongan khawas, Nasr percaya adanya individu-individu istimewa yang sengaja dipilih oleh Tuhan sebagai penunjuk jalan bagi golongan yang lain. Mereka, karena dipilih, tidak mustahil berhasil mencapai maqâm (stasiun) tertinggi dalam tasawuf. Sedangkan bagi golongan masyarakat awam dipandang cukup dengan menempuh kehidupan sesuai dengan ajaran syariat agar dapat masuk surga. Akan tetapi, bagi mereka yang ingin mencapai realitas ruhani yang lebih sempurna, maka Islam juga telah menyediakan sarana untuk itu, yaitu tasawuf. ${ }^{44}$

Demikian uniknya pengamalan tasawuf, Nasr mengingatkan, bagaimanapun dalam melakukan perjalanan spiritual (tasawuf) harus ditempuh dengan bimbingan seorang syaikh, mursyid atau pir terpercaya, yang memungkinkan terjadinya kelahiran kembali

${ }^{42}$ Malâmatiyyah adalah segolongan orang-orang tasawuf yang muncul di Nisyapur dan sekitarnya, sejak paruh kedua abad ke-9 $(3 \mathrm{H})$ sampai awal abad ke-11 $(5 \mathrm{H})$. Mereka disebut demikian, karena mereka berupaya terus-menerus melakukan malâmat (celaan, kritik, atau koreksi) terhadap keadaan batin atau jiwa mereka sendiri. Upaya demikian mereka pandang sebagai metode terbaik untuk menghindari kelengahan diri dan sekaligus memacu jiwa untuk senantiasa berjuang meningkatkan kualitas batin dalam rangka mendekatkan diri pada Allah. Lihat Harun Nasution (ed.)., Ensiklopedi Islam Indonesia (Jakarta: Djambatan, 1992), h. 607. Lihat juga Seyyed Hossein Nasr, Ensiklopedi Tematis Spiritual Islam (Bandung, Mizan, 2002), h. 278-279.

${ }^{43}$ Bagir, Buku Saku Tasawuf, h. 144-146.

${ }^{44}$ Seyyed Hossein Nasr, Sufi Essays (New York: Caravan Book, t.t.), h. 57. 
mencapai transformasi ruhani. Demikian sentralnya peran seorang syaikh, mursyid atau pir dalam tasawuf, karena menurut Nasr, ada hubungan antara seorang syaikh atau mursyid dengan Rasulullah SAW. melalui silsilah yang dilengkapi fungsi untuk melakukan inisiasi (wilâyah) yang menyatu (inheren) dengan misi kenabian, karena itu seorang syaikh atau mursyid sufi mampu mengeluarkan muridnya dari lingkungan dunia material untuk masuk ke dalam kehidupan ruhani yang amat luas tidak bertepi. Lebih jauh ditegaskan Nasr, bahwa tidak ada jalan keruhanian asli yang mungkin tanpa guru, apalagi tasawuf. Guru sufi adalah wakil dari peranan esoterik Nabi Muhammad SAW., dan dengan cap yang sama ia adalah alamat dari rahmat Tuhan yang menyediakan diri kepada mereka yang ingin berpaling kepadanya. Syarî́ah (hukum Tuhan) diperuntukan bagi seluruh orang Islam, bahkan bagi seluruh umat manusia. Akan tetapi, tarekat (tasawuf) hanya diperuntukkan bagi mereka yang mencari Tuhan dan yang mencari Kebenaran di balik yang berubah ini, yang walaupun hadir di sini dan sekarang, pada saat yang bersamaan merupakan sumber semua wahyu yang transenden dan kekal. Tarekat (tasawuf) dengan demikian merupakan upaya di mana manusia dapat kembali kepada sumber wahyu keislaman sendiri dan menjadi, dalam arti keruhanian, baik sebagai sahabat maupun sebagai penerus Nabi Muhammad SAW. dan para wali. ${ }^{45}$

Manusia mengalami masa tua, renta dan mati, sementara orang yang dikarunia kekayaan rohani selalu tetap muda secara batin. Setelah mabuk meminum dari sumber kehidupan yang kekal dan setelah memperoleh kedekatan dengan mukjizat kebakaan ia hidup di musim semi jiwa yang langgeng, bahkan juga tubuhnya berhasil melalui musim dingin kehidupan. Itulah sebabnya guru mampu memberikan kemudaan kepada muridnya, berapa pun usianya. Menyaksikan guru yang sempurna adalah memperoleh puncak nikmat dan kegembiraan musim semi hidup, dan terpisah dari guru adalah merasakan dukacita umur tua. Rûmî menuturkan "aku menjadi tua oleh bencana, tapi kala Tabriz kau sebut, seluruh mudaku kembali kepadaku lagi." ${ }^{46}$

Orang mungkin mencari sumber hidup sendiri. Ia mungkin berusaha menemukan prinsip-prinsip pewarisan kerohanian melalui usaha-usahanya sendiri. Tetapi usaha ini akan sia-sia dan takkan pernah memberikan hasil sebelum seorang guru hadir bersama muridnya yang hanya dia saja yang dapat memberikannya. Tanpa batu filosuf tak mungkin terjadi perubahan kimia. Hanya kuasa syeik yang dapat membebaskan seseorang dari dirinya dan nafsu rendahnya. Demikian pula gurulah yang memungkinkan seseorang menyaksikan alam semesta sebagaimana adanya sesungguhnya dan menyeru laut Kebenaran Universal. Rûmî menegaskan "tanpa kuasa raja Syams al-Haqq dari Tabriz, seseorang tidak bisa melihat bulan dan menjelma laut." 47

${ }^{45}$ Ibid.

${ }^{46}$ R. A. Nicholson, Selected Poems from Divani Shamsi Tariz (Cambridge, 1952), h. 25.

${ }^{47}$ Ibid., h. 79 
Untuk melakukan pendakian spiritual, seorang sufi harus melalui jenjang stasiunstasiun (maqâmât) spiritual yang dikenal dalam tasawuf secara bertahap. Maqâmât tersebut mulai dari bawah yaitu taubat, zuhud, warak, fakir, sabar, tawakal, rida dan seterusnya. Dalam menyikapi banyaknya variasi susunan maqâmât yang dikemukakan para sufi, Nasr tidak menentukan pilihan salah satu pandangan lalu membuang yang lain, tetapi ia hanya mengemukakan teori maqâmât dalam tasawuf secara umum. Namun, ia tetap menekankan bagi mereka yang ingin menjadi sufi secara total, maqâmât tersebut harus dilalui mulai dari jenjang yang paling bawah sampai ke tingkat yang teratas. ${ }^{48}$

\section{Pandangan Barat terhadapTasawuf}

Seperti sudah dijelaskan, baik tasawuf maupun syariat kedua-duanya bersumber dari al-Qur'an dan Sunnah Nabi. Namun demikian, menurut Nasr, jarang ada sarjana Barat yang mempelajari Islam yang menyadari bahwa akar tasawuf terdapat dalam alQur'an. Sebenarnya, bertahun-tahun yang lalu Massignon telah menulis bahwa dengan membaca al-Qur'an beberapa kali saja sudah cukup untuk menyadarkan orang bahwa tasawuf bersumber dari al-Qur'an. Margoliuth juga mengakui al-Qur'an sebagai sumber tasawuf; dan tentunya juga Corbin, yang memiliki pandangan berbeda dengan kebanyakan orientalis dan melakukan penelitiannya tentang Islam dengan rasa keikutsertaan, telah memastikan kenyataan essensial ini berkali-kali. Tetapi sebagian besar pengarang Barat, barangkali karena tidak mau mengakui kehadiran dimensi spiritual dalam Islam, telah mengajukan berbagai teori tentang asal usul tasawuf, teori yang sesungguhnya hanya menyinggung ekspresi lahir tasawuf dan bukan tasawuf yang sebenarnya. ${ }^{49}$

Ada yang berpendapat bahwa tasawuf terbentuk karena pengaruh Neoplatonisme, monatisisme Kristen, "reaksi Arya" terhadap agama semit, Zoroastrianisme, Manichaeaisme, Hinduisme, dan Buddhisme. Di dalam setiap kasus, beberapa persamaan bentuk atau bahkan peminjaman metode atau ekspresi tertentu ditonjolkan sebagai bukti tentang asal usul tasawuf yang non-Islam. Tetapi apa yang ada di balik argumen ini hampir selalu berupa

\footnotetext{
${ }^{48}$ Para sufi abad ketiga hijriyah membicarakan tingkatan-tingkatan (maqâmât) dan penemuanpenemuan kerohanian (a $\underline{h} w a \hat{l}$ ) yang harus dilalui satu demi satu oleh setiap calon sufi (sâlik). Jumlah dan urutannya tidak ada kesepakatan antara para penulis sufi yang menjelaskannya. Al-Sarrâj menjelakan tujuh maqâmât (taubat, warak, zuhud, fakir, sabar, tawakal, dan rida), dan sepuluh a ȟwâl (muraqabah, kedampingan, cinta, takut, harap, rindu, tentram, memandang Tuhan dan yakin). Sedangkan Abû Thâlib al-Makkî menjelaskan lebih banyak lagi. Tetapi seluruhnya bermula dari taubat, dan secara keseluruhannya, apa yang yang disebut maqamat itu mencerminkan proses perkembangan kejiwaan sufi seperti apa yang disebut purgative, illuminative, dan unitive stages, dalam istilah mistik Barat. Lihat al-Sarrâj, Al-Luma' (t.t.p.: t.p., t.t.), h. 70104; Abû Thâlib al-Makkî, Qût al-Qulûb (Kairo: t.p., 1332 H), h. 364-530; Nasr, Sufi Essays, terutama bab V (The Spiritual States in Sufism), h. 68-83.

${ }^{49}$ Lebih lanjut lihat Abû al-Wafa' al-Ghanimi al-Taftazani, Madkhal ilâ al-Tashawwuf al-Islâmî (Kairo: Dâr al-Tsaqâfah li al-Thibâ‘ah wa al-Nasyr, 1979), h. 23-34; Nasr, Ideals and Realities of Islam, h. 127.
} 
asumsi apriori bahwa Islam bukanlah wahyu Tuhan dan karena itu tidak mungkin memiliki dimensi spiritual yang asli. Ada keyakinan yang telah lama berakar di dunia Barat bahwa Islam hanyalah agama kekerasan yang telah membentuk tata masyarakat dengan paksaan, ${ }^{50}$ sehingga semua hal yang bersifat kontemplatif dan metafisis di dalamnya pasti merupakan peminjaman dari luar. Apa yang terlampaui dari pandangan mereka yang mengajukan teori tentang sumber tarekat yang eksternal adalah sifatnya sebagai petunjuk spiritual. Jalan spiritual adalah petunjuk dengan mana orang akan mampu mengatasi batas-batas manusiawi dan mendekati yang agung. Karenanya, jalan-jalan itu bukanlah ciptaan manusia. Mencoba untuk mengatasi sifat manusiawi dengan sesuatu yang diciptakan manusia adalah absurd. Setiap orang yang mengakui adanya kehidupan spiritual harus mengakui bahwa jalan hidup tersebut mengandung karunia yang bukan ciptaan manusia, bahwa ia haruslah sebuah jalan yang diciptakan Tuhan dan ditempatkan di hadapan manusia untuk ditempuh. ${ }^{51}$

Kebenaran yang mendasar ini dapat diterapkan pula dalam tasawuf. Kata Nasr, tasawuf dalam Islam adalah jalan spiritual yang dapat menghasilkan kesucian, yang buahnya menunjukkan asal usul yang suci melalui keharuman spiritual yang menyertainya; atau ia dipinjam dari luar Islam, yaitu dipinjam dan diciptakan oleh manusia sehingga dalam hal mana ia bukanlah jalan spiritual. Jika tasawuf dapat menciptakan orang-orang yang suci dan memiliki kekuatan spiritual, maka tentunya barakah yang memungkinkan transformasi jiwa tersebut berasal dari sesuatu Yang Suci, dan lebih dari pada itu, berasal dari sumber wahyu Islam sendiri. Barakah itu harus berupa "barakah Muhammadiyah", sebab barakah Kristen atau Buddha tentu tidak akan mampu menciptakan seorang Muslim yang suci, yang menjadi tanda kelebihan religius Islam, seperti juga barakah Muhammadiyah tidak bisa menciptakan seorang Kristen atau Budha yang suci. Dalam kedua hal ini, barakah dari bentuk tradisi lain akan bisa, dalam keadaan tertentu, membantu ke arah kesadaran tentang tujuan spiritual. ${ }^{52}$

Nasr menegaskan bahwa bagi mereka yang menolak otentika kehidupan spiritual, argumen serupa itu tidak mempunyai arti apa-apa, tetapi orang tentunya tidak dapat menerima otentika, misalnya spiritualitas Kristen dan menolak spiritualitas Islam dengan berpegang pada argumen historis murni. Di dalam setiap tradisi pohon spiritual memiliki akar di dalam sumber tradisi tersebut. Setiap pemeluk Kristen akan menganggap absurd setiap pernyataan bahwa spiritualitas St. Augustinus berasal dari Yunani karena ia memahami Platonisme dan Neoplatonisme, sebab ia tahu bahwa St. Augustinus menjadi seorang Santo bukan dengan membaca tulisan-tulisan para filosuf, melainkan melalui karunia

${ }^{50}$ Lebih lanjut baca apendik 3 "Pandangan Barat tentang Islam, Hasil Sejarah Panjang" dalam Thâriq Ramadlân, Menjadi Modern Bersama Islam, terj. Zubair dan Ilham Saenong (Jakarta: Teraju, 2003), h. 421-429.

${ }^{51}$ Nasr, Ideals and Realities of Islam, h. 128.

${ }^{52}$ Ibid. 
Kristus. Bijak bestari Yunani seperti Plato dan Plotinus hanya memberikan kepadanya bahasa yang tepat untuk mengekspresikan kebenaran Kristen. Tetapi ada beberapa orang yang tidak menyadari bahwa juga merupakan hal yang absurd untuk mengatakan bahwa spiritualitas al-Hallâj atau Ibn 'Arabî atau Rûmî bersifat non-Islam karena mereka berbicara tentang cinta yang menyerupai ajaran Kristen atau menggunakan perumusan doktriner yang dipinjam dari Neoplatonisme atau juga Hermetisisme. Yang membuat mereka menjadi orang-orang suci bukanlah ide ini atau itu yang pernah diucapkan oleh bijak bestari Kristen atau Yunani tertentu, melainkan berkah Muhammad, kehadirannya yang dikandung oleh metode dan teknik tasawuf. Mereka adalah buah pohon spiritual Islam dan tidak ada pohon dapat berbuah kecuali bila akarnya tertanam kokoh di tanah tempat tumbuhnya. Dalam hal pohon spiritual "tanah" tersebut haruslah berupa wahyu Tuhan dan akarnya harus berupa ikatan langsung yang menghubungkan setiap manifestasi spiritual dalam suatu tradisi dengan sumbernya. ${ }^{53}$

Nasr menambahkan, sebagai perbandingan perlu dikemukakan bahwa tasawuf juga mempunyai pengaruh atas gerakan Bhakti di India dan beberapa orang suci Hindu, bahkan telah menulis sajak-sajak mistik yang didasarkan pada sajak-sajak sufi Persia. Tetapi apabila mereka ini betul-betul orang suci, waktu mereka bersemadi dan menyebut nama "Rama" atau nama suci lainnya, yang hadir adalah kekuatan yang timbul dari tradisi Hindu dan menunjukan kekuasaannya dengan membuat mereka menjadi orang suci, yang di dalam anggapan pemeluk Hindu adalah inkarnasi dari kekuatan spiritual Hinduisme. Bukan sajak-sajak sufi yang membuat mereka menjadi orang suci melainkan kehadiran kekuatan spiritual Hinduisme sendiri, meskipun di India dalam Abad Pertengahan, di mana terdapat dua tradisi keagamaan besar secara bersamaan, sering kali seseorang tersentuh oleh kekuatan spiritual tradisi lain. Di sini terlihat kembali bahwa setiap tradisi memiliki norma spiritual tersendiri, yang tampak dengan jelas pada orang-orang suci dalam tradisi tersebut. ${ }^{54}$

Kesalahan pandangan orientalis tentang usul-usul tasawuf disebabkan karena pandangan tersebut mengacaukan tinjauan tentang keseluruhan struktur Islam, dan tidak memungkinkan pemahaman yang sebenarnya tentang tasawuf. Jika tasawuf dianggap sebagai sesuatu yang dipinjam dari luar, maka Islam di mata orang asing akan dianggap sebagai sistem sosial politik belaka, yang tidak berhubungan dengan kebutuhan spiritual menusia yang paling dalam. Pengabaian studi tentang Islam di bidang perbandingan agama adalah karena diabaikannya aspek Islam yang kontemplatif dan yang sering dianggap tidak asli. Lagi pula, tasawuf tidak dapat dipahami dengan baik dan dibahas dengan serius sebelum disadari bahwa tasawuf, atau dimensi esoterik Islam, seperti gejala aspek ortodoksi Islam didasarkan pada al-Qur'an dan hadis. ${ }^{55}$

\footnotetext{
${ }^{53}$ Nasr, Ideals and Realities of Islam, h. 129.

${ }^{54}$ Ibid.

${ }^{55}$ Ibid., h. 130.
} 
Upaya untuk menjawab tuduhan keliru para orientalis Barat tentang asal usul tasawuf juga dilakukan oleh para ulama lain. Di antaranya adalah Abû al-Wafâ' al-Ghanîmî alTaftâzânî yang menulis buku Madkhal ilâ al-Tashawwuf al-Islâmî (Kairo: Dâr al-Tsaqâfah li al-Thibâ‘ah wa al-Nasyr, 1979). Dalam kitab tersebut, ia mengetengahkan pandangan keliru dari para orientalis yang menganggap bahwa tasawuf bersumber dari luar Islam. Di antaranya adalah Thouluck, seorang orientalis dari abad ke-19, yang menganggap bahwa tasawuf ditimba dari sumber Majusi, dengan alasan bahwa sejumlah besar orangorang Majusi di Iran Utara, setelah penaklukan Islam, tetap memeluk agama mereka, dan banyaknya tokoh sufi yang berasal dari sebelah utara kawasan Khurasan. Di samping itu, kenyataan bahwa sebagian pendiri aliran-aliran sufi angkatan pertama berasal dari kelompok orang-orang Majusi. Orientaris lain, yaitu Dozy, yang berpendapat bahwa tasawuf dikenal oleh kaum Muslim lewat orang-orang Persia yang telah berkembang di sana karena diajarkan orang-orang India sebelum datangnya Islam. Sejak masa purba, di Persia telah hidup suatu gagasan yang menganggap bahwa asal-muasal timbulnya segala sesuatu adalah dari Tuhan, semesta ini tidak mempunyai wujud tersendiri, dan wujud yang riil hanyalah Tuhan. ${ }^{56}$

Sekelompok orientalis lain (seperti Von Kramer, Ignaz Goldziher, Asin Palacios, dan O'leary) beranggapan bahwa tasawuf berasal dari sumber Kristen. Dengan alasan, adanya suatu interaksi antara orang-orang Arab dan kaum Nasrani pada masa jahiliyah maupun zaman Islam; adanya segi-segi persamaan antara kehidupan asketis ataupun sufi, dalam ajaran serta tata cara mereka ketika melatih jiwa dan mengasingkan diri, dengan kehidupan al-Masih dan ajaran-ajarannya, dan dengan para rahib dalam cara mereka beribadat dan berpakaian. ${ }^{57}$

Kaum orientalis lainnya, seperti M. Horten dan R. Hartman, berpendapat bahwa tasawuf ditimba dari sumber India. Mereka berpendapat sebagian teori tasawuf dan bentukbentuk dari latihan ruhaniahnya menyerupai bentuk-bentuk dan latihan-latihan dalam mistisisme orang-orang India, karena itu mereka berkesimpulan bahwa tasawuf berasal dari aliran Vedanta di India. ${ }^{58}$

Menanggapi beberapa pandangan para orientalis tersebut, al-Taftazani menegaskan, para sufi tidaklah sekedar menukil orang-orang Persia, Kristen, dan India, karena tasawuf pada dasarnya berkaitan dengan perasaan dan kesadaran. Jiwa manusia adalah satu, sekalipun terdapat perbedaan bangsa atau rasnya. Apapun yang berkaitan dengan jiwa manusia, lewat latihan-latihan ruhaniah, memang bisa saja sama, meskipun tidak terjadi kontak antara keduanya. Ini berarti adanya benang merah di antara pegalaman para sufi, betapapun berbedanya interpretasi antara seorang sufi yang satu dengan yang lainnya

\footnotetext{
${ }^{56}$ Al-Taftâzânî, Madkhal ilâ al-Tashawwuf, h. 23.

${ }^{57}$ Ibid., h. 24-25.

${ }^{58}$ Ibid., h. 27-28.
} 
sesuai dengan beragam budaya di mana mereka hidup. Atas dasar ini, maka terdapatnya kesamaan antara tasawuf dengan berbagai bentuk mistisisme asing tidak selalu berarti bahwa gagasan tasawuf ditimba dari sumber-sumber lain. Yang lebih tepat adalah gagasan tasawuf muncul dari kaum Muslim sendiri. Sebab, pengetahuan mereka, seperti kata mereka, muncul dari intuisi dan pemahaman mereka sendiri terhadap sumber-sumber agama Islam baik al-Qur'an maupun hadis. Lebih lanjut, Abû al-Wafâ' al-Ghanîmî al-Taftâzânî menegaskan, semua tingkatan (al-maqâmât) dan keadaan kejiwaan (al-aḩwâl) para sufi, yang pada dasarnya merupakan obyek utama tasawuf, semuanya berlandaskan al-Qur'an. ${ }^{59}$

\section{Penutup}

Sebagai agama kesatuan (tawhîid), semua aspek ajaran dan praktik Islam yang benar menunjukkan prinsip yang sentral dan penting ini. Syariat Islam merupakan jaringan amanat dan aturan yang luas yang mempertalikan dunia yang jamak secara batin dengan Pusat Yang Tunggal, yang berbeda dengan kemajemukan yang berada di sekitarnya. Tasawuf sebagai intisari (dimensi dalam) wahyu Islam adalah sebagai upaya yang luhur untuk mencapai tauhid. Seluruh jalan keruhanian (tharîqah) dalam tasawuf bertujuan membebaskan manusia dari penjara kemajemukan, mengobati manusia dari kemunafikan dan membuatnya menjadi manusia yang utuh, karena hanya dengan keutuhan itulah manusia dapat menjadi suci. Dengan kata lain, tujuan utama tasawuf adalah pengutuhan manusia dengan seluruh kedalaman dan keluaran keberadaannya dan seluruh keluasan yang tercakup dalam pribadi manusia, yang kemudian terkenal dengan sebutan manusia sempurna (al-insân al-kâmil). ${ }^{60}$ Tasawuf yang bertujuan tercapainya kesadaran murni dan menyeluruh ini, bukan dengan meniadakan akal seperti dilakukan dalam praktik kesalehan gerakan keagamaan modern, tetapi melalui pengetahuan tiap unsur dari wujud seseorang menuju pusatnya sendiri yang benar. Manusia yang terdiri dari tubuh, pikiran (mind) dan jiwa (spirit) masing-masing perlu diutuhkan menurut tingkatnya sendiri. Meskipun tubuh merupakan aspek paling luar dari manusia, memiliki keberadaan obyektif dan ragam tindakan sendiri, ia bukanlah rintangan paling besar dalam upaya pengutuhan itu. ${ }^{61}$

Ajaran tasawuf diperlukan bagi manusia yang pikirannya kebingungan sebagai suatu pengetahuan teoritis tentang susunan kenyataan dan tempat manusia di dalamnya. Ia

${ }^{59}$ Ibid., h. 31-32.

${ }^{60}$ Sejalan dengan pandangan Nasr ini, Muhammad Zakî Ibrâhîm menegaskan bahwa tasawuf, sebagai inti ajaran Islam, mengajarkan manusia untuk menjadi manusia merdeka, mengajarkan manusia untuk menjadi pemimpin bagi dirinya sendiri. Tasawuf mengajarkan manusia untuk menaklukkan hawa nafsu dan syahwatnya serta mengalahkan setan. Tasawuf mengajak manusia meninggalkan semua bentuk pengabdian kecuali hanya kepada Allah. Tasawuf adalah kebebasan mutlak dari setiap pengaruh kebendaan dan hawa nafsu, sebab seorang sufi adalah seorang yang telah menyelami makna lâ ilâha illâ Allâh (tiada Tuhan selain Allah). Muhammad Zakî Ibrâhîm, Abjâdiyyat al-Tashawwuf al-Islâmî, h. 155.

${ }^{61}$ Nasr, Sufi Essays, h. 43-44. 
dengan sendirinya adalah hasil dari penglihatan ruhani para salik dan wali yang, setelah mencapai martabat kesemestaan, telah diberi penglihatan tentang semesta. Dengan demikian, ia berdiri di awal dan akhir jalan kerohanian. Peranan ajaran tasawuf dalam pengutuhan pikiran dan kehidupan manusia modern merupakan suatu hal yang sangat mendesak tidak bisa dihindari.

\section{Pustaka Acuan}

Arberry, A.J. Sufism: An Account of the Mysticof Islam. London: George Allen and Unwin Ltd., 1979.

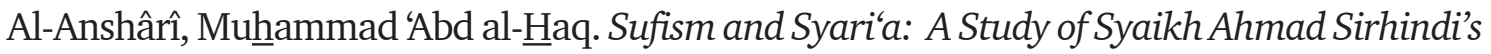
Effort to Reform Sufism. Jakarta: Rajawali. 1990.

Bagir, Haidar. Buku Saku Tasawuf. Bandung: Arasy-Mizan Utama, 2005.

Al-Ghazâlî, Abû Hâmid Muhammad ibn Muhammad. Ihyyâ' 'Ulûm al-Dîn. Juz I-IV. Beirut: Dâr al-Fikr. 1980.

Al-Hujwîrî, Abû al-ㅂasan ‘Âlî ibn 'Utsmân. Kasyfal-Mahjûb. trans. R.A. Nicholson. London, 1976.

Ibn 'Arabi. Al-Futûhâat al-Makkiyyah. 4 Vol. Beirut: Dâr al-Fikr. t.t.

Ibrâhîm, Muhammad Zakî. Abjâdiyyat al-Tashawwuf al-Islâmî. Kairo: al-Asyîrah alMuhammadiyyah. 1989.

Al-Kalâbâdzî, Abû Bakr Muhammad. The Doctrine of the Sufis. trans. A.J. Arberry. Lahore: Sh. Muhammad Ashraf, 1979.

Al-Makkî, Abû Thâlib. Qût al-Qulûb. Kairo: t.p.. 1332 H.

Al-Naisâbûrî, Abû al-Qâsim al-Qusyairî. Risâlah al-Qusyairiyyah fì 'Ilm al-Tashawwuf. Beirut: Dâr al-Khair, t.t.

Nasr, Seyyed Hossein. Ensiklopedi Tematis Spiritual Islam. Bandung. Mizan. 2002.

Nasr, Seyyed Hossein. Ideals and Realities of Islam. Chicago: ABC International, 1999.

Nasr, Seyyed Hossein. Islamic Life and Thought. Chicago: ABC International, 2001.

Nasr, Seyyed Hossein. Sufi Essays. New York: Caravan Book, t.t.

Nicholson, R. A. Selected Poems from Divani Shamsi Tariz. Cambridge. 1952.

Noer, Kautsar Azhari. Tasawuf Perenial Kearifan Kritis Kaum Sufi. Jakarta: Serambi, 2002.

Noer, Kautsar Azhari. "Memahami Tasawuf: Suatu Tanggapan terhadap Beberapa Tuduhan," dalam Ahmad Najib Burhani (ed). Manusia Modern Mendamba Allah Renungan Tasawuf Positif. t.t.p.: t.p., t.t.

Nasution, Harun (ed.). Ensiklopedi Islam Indonesia. Jakarta: Djambatan. 1992.

Al-Naisâbûrî. Risâlah al-Qusyairiyyah fĩ 'Ilm al-Tashawwuf. Beirut: Dâr al-Khair. t.t.

Al-Randî, Muhammad ibn Ibrâhîm. Syarh al- $\underline{H} i k a m$. Singapura \& Jeddah, t.t. 
MIQOT Vol. XXXVII No. 2 Juli-Desember 2013

Ramadhân, Thâriq. Menjadi Modern Bersama Islam, terj. Zubair dan Ilham Saenong. Jakarta: Teraju, 2003.

Al-Sarrâj. Al-Luma'. t.t.p.: t.p., t.t.

Schuon, Frithjof. Understanding Islam. trans. Macleod Matheson. London: Allen and Unwin. 1963.

Al-Taftazani, Abû al-Wafa' al-Ghanimi. Madkhal ilâ al-Tashawwuf al-Islâmî. Kairo: Dâr al-Tsaqâfah li al-Thibâ‘ah wa al-Nasyr, 1979. 